A number of facts militates strongly against the Henry Mountains explanation of loccolithic protuberance. Three basic premises appear wholly untenable. Most vitiating is the seeming incompetency of simple hydrostatic pressure to produce the desired results. Inadequacy of relative lithologic density is now commonly conceded. There also appears to be a radical disparity between the physical conditions accompanying the formation of laccoliths and their once supposed nearest kin the sills.

On the other hand the recent unearthing of the infrabasal make-up of certain laccoliths clearly points to a fundamental dependence of this class of mountains upon prior geologic structure. The shape of laccolithic masses is found to be cuneiform instead of lenticular; and thus at once does away with the blister idea. Quite essential appears to be the presence of crustal lines of weakness. The magmatic swelling or localization of laccoliths is discovered to be a direct function of orographic potentialities.

In seeking an immediate cause for his laccolithic intrusion Professor Gilbert did not lose sight of certain mechanical shortcomings of his explanation. These he sought to overcome by appealing to certain associated factors, which, however, later, Doctor Cross showed to be both unnecessary and not demonstrated as such. Professor J. D. Dana got over the difficulties by brushing aside all considerations except simple hydrostatic pressure and with this feature alone regarded the Gilbertian hypothesis complete. This is doubtless one of the main reasons why from a mechanical angle leading European geologists have so persistently challenged the American view of laccolithic intrusion. At the same time Old World writers on the theme offer no alternative theory to take the place of the one which they seek to discredit. Through the results of close inspection of certain laccoliths of northern New Mexico the chief objections which were raised against the Gilbert view seem to be fully met. Controlling tectonic factors which all describers of laccoliths have missed thus appear to supply the long sought desiderata.

As) a primary consideration in order that a laccolith be produced rather than any other form of volcanic manifestation it appears that the intrusive mass shall have a particular tectonic setting. Profound faulting is one of these prime factors. Another is orographic flexing by which the rigidity of certain arching strata largely maintains the load of superincumbent materials. Probably the high viscosity of acidic magmas has an important but as yet uncalculated influence on events. The remarkable infrabasal structure which the New Mexico laccoliths reveal carries the inquiry a step more remote and explains the deep-seated cause of the major faulting, whereby an orographic prism is sustained by a sharp Pre-Cambrian arch, the rigidity of which is not even yet lost although the adjoining blocks on either side are allowed to sliele down, as it were, the steep sides of the old flexure.

Now at the southern terminus of the Rocky Mountain Cordillera, in northern New Mexico, there is a succession of open flexures, the amplitude of which grows less as they recede from the main axis. It is where these folds cross great fault lines that laccoliths form. Thus through direct mathematical analysis of the tectonic problems presented and in the satisfaction of the most urgent tectonic demands an adequate raison d'être for laccolithic genesis and location seems to be offered.

\section{Charles Keyes}

\section{SOIL REACTION AND THE PRESENCE OF AZOTOBACTER}

During the summer of 1917 the writer conducted a preliminary survey of local soils to ascertain the relative nitrogen-fixing ability and prevalence of Azotobacter. Ninety soils were collected within two miles of the laboratory. The samples were taken from as widely varying soil conditions as could be located including the following: cultivated, permanent alfalfa, bluegrass sod, native pasture, barren hilltops, river bottom, sand bar, rọadside and forest. 
When cultured in a standard alkaline mannite solution 41 per cent. of the soils failed to show any Azotobacter growth. The average nitrogen fixed, per 100 c.c. cultural solution, in such cultures was $7.76 \mathrm{mg}$. The average nitrogen fixed in cultures showing Azotobacter was $16.22 \mathrm{mg}$. per 100 c.c. cultural solution.

A study of the reaction of these soils gave very interesting results. The hydrogen ion concentration of an aqueous extract of the soils was measured by the colorimetric method outlined by Clark and Lubs. ${ }^{1}$

The range of hydrogen ion concentration in the soil extracts, prepared by shaking one part of soil with one part of water and centrifuging expressed in $\mathrm{P}_{\mathrm{H}}$ was from 5.3 to 7.8. All of the extracts from soils which developed Azotobacter, with the exception of three, gave a $\mathrm{P}_{\mathrm{H}}$ of 6.0 or above. All of those which failed to give Azotobacter, with the exception of three, gave a $\mathrm{P}_{\mathrm{H}}$ of 5.9 or less. These results would indicate that the absolute reaction is probably the major factor controlling the presence of Azotobacter in soils.

\section{P. I. GAINEY}

Research Laboratory in SoIl Bacteriology, Kansas Agricultural Exper. Sta.

\section{DESIGNATION OF SPECIALIZING PHYSICISTS}

Physicists specializing along certain definite lines in such a way or to such a degree that the broad term physicist is not suffciently descriptive of their professional activities, are frequently at a loss for a suitable designation. For example, a physicist engaged in industrial physics along the lines of electricity may not consider himself an electrical engineer, and still less an "electrician" in the ordinarily accepted use of the term. What shall he call himself? A physicist specializing in mechanics may be neither a mechanical engineer nor a mechanic or mechanician. Similarly one specializing in heat may not be a heating engineer, and one in light may be no optician. The specialist in sound who is now coming into recognition more and more has not even the restricted range of choice given to the others cited.

1 Journal of Bacteriology, Vol. 2, Nos. 1, 2 and 3.
The answer proposed to the above problem involves a new set of designations of the main subdivisions of the broad science of physics, designations obvious enough in themselves, which commend themselves as logical and acceptable from a terminological standpoint, quite apart from the solution thereby offered of the question raised in the foregoing. It will be noted that the terms being derived from the classic Greek, are international. The following table will make the matter clear.

\begin{tabular}{lll}
\multicolumn{1}{c}{ The Sclence of } & Proposed Designation & $\begin{array}{c}\text { Designation of } \\
\text { Speclalist }\end{array}$ \\
Mechanics & Mechanology & Mechanologist \\
Sound & Phonology & Phonologist \\
Heat & Thermology & Thermologist \\
Light & Photology & Photologist \\
Electricity & Electrology & Electrologist \\
Magnetics & Magnetology & Magnetologist \\
Radiation & Radiology & Radiologist
\end{tabular}

A suggested sample definition is as follows: A mechanologist is a person who is versed in the science of mechanics, or mechanology, and who may, in addition, be skilled in applying the science.

The terms proposed are so obvious that there is no need to make an extended argument in favor of their adoption. The proposals are made with the thought that the need for such terms will become more and more evident through the increased entrance of physics and physicists into industrial and practical work, and it is well that a suitable terminology should be ready at hand for adoption as required.

Clayton H. Sharp

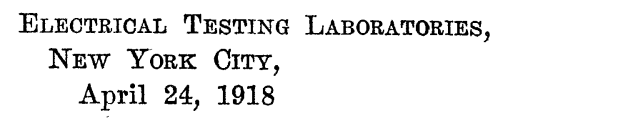

\section{SCIENTIFIC BOOKS}

The Science and Practice of Photography. By John R. Roebuck. New York, D. Appleton and Company. 1918. Pp. VIII + 298. $\$ 2.00$.

In this book Dr. Roebuck publishes the course in photography which has been given under his direction at the University of Wisconsin. 